\title{
PENGARUH STRES DAN KEPUASAN KERJA TERHADAP KEMANGKIRAN (ABSENTEEISM) PEGAWAI DINAS PENDIDIKAN, PEMUDA DAN OLAHRAGA KOTA BUKITTINGGI PROVINSI SUMATERA BARAT
}

\author{
Husnul Alimah Z. Day*
}

\begin{abstract}
The purpose of this research is to know the effect of stress and job satisfaction toward the Authorities of Education, Youth and Sport of Bukittinggi, West Sumatera Employee's absenteeism. The research was conducted by using survey method with quantitative approach and path analysis technique. The population of this research is 103 personnel. Research samples selected as much as 82 personnel using simple random sampling technique. The data obtained through questionnaires and analyzed by using path analysis techniques. Based on the results of the data analysis in this research it is concluded: (1) stress has direct positive effect to absenteeism; (2) job satisfaction has direct negative effect to absenteeism; (3) stress has negative effect to job satisfaction
\end{abstract}

Keywords: Kemangkiran, stres, and kepuasan kerja.

\section{PENDAHULUAN}

Dinas Pendidikan, Pemuda dan Olahraga Kota Bukittinggi Provinsi Sumatera Barat sebagai suatu lembaga pendidikan dituntut untuk mampu menghadapi tantangan dan masalah dalam pengelolaan lembaga yang berkualitas, termasuk masalah kemangkiran pegawai. Hal ini mengingat pegawai merupakan salah satu komponen lembaga yang memiliki peranan yang sangat penting dalam mencapai tujuan yang ingin dicapai. Perilaku pegawai dalam bekerja yang tidak dapat menyelesaikan pekerjaan sesuai jadwal terlihat dari kegagalan pegawai untuk melaporkan pekerjaan atau tetap bekerja sesuai jadwal, kegagalan pegawai dari menyelesaikan tugas sesuai jadwal dan ketidakhadiran pegawai pada jam kerja.disebut dengan kemangkiran. Kepuasan kerja seorang pegawai mempengaruhi kemangkiran yang terjadi. Pada saat pegawai menilai pekerjaan dapat memberikan kesenangan dan memberi hasil yang dinilai memuaskan, maka pegawai akan lebih rajin untuk melaksanakan pekerjaannya. Kepuasan kerja mampu menumbuhkan semangat dalam diri pegawai. Dengan adanya semangat bekerja inilah pegawai dapat menekan tingkat kemangkirannya. Kemangkiran juga direduksi dengan adanya stres. Stres disebabkan oleh berbagai hal, diantaranya adalah rasa tidak nyaman pegawai yang bekerja di bawah tekanan dari pimpinan dan masalah pribadi yang dialaminya di dalam maupun di luar organisasi. Jika pegawai mengalami stres yang tidak mampu dikelolanya dengan baik maka akan mengalami penurunan hasil kerja, ketidakpuasan, dan tidak jarang berujung pada kemangkiran

\footnotetext{
* Staf Pengajar Diniyyah Puteri Padang Panjang.
} 
dan turnover. Maka dari itu peneliti ingin mengkaji secara ilmiah apakah stres dan kepuasan kerja berpengaruh terhadap kemangkiran.

\section{Kemangkiran}

Menurut Anderson (2001:233)," defines absenteeism as 'the failure to report for scheduledwork' Martocchio and Harrison (1993: 263) define it as 'an individual's lack of physical presence at a given location and time when there is a social expectation for him or her to be there.'thus, absence is the logical opposite of attendance". Kemangkiran didefenisikan sebagai kegagalan untuk melaporkan pekerjaan yang telah terjadwal. Kemangkiran juga didefenisikan sebagai kelemahan individu dalam hal kehadiran pada tempat dan waktu yang telah ditentukan di saat ada harapan sosial bahwa mereka bisa hadir. Oleh karena itu, kemangkiran merupakan lawan dari kehadiran.

Sedangkan menurut Cascio dan Boudreau (2011:58)," absenteeism is any failure of an employee to report for or to remain at work as scheduled, regardless of reason". Kemangkiran adalah kegagalan karyawan untuk melaporkan pekerjaannya atau tetap bekerja sesuai jadwal tanpa harus memperhatikan alasannya. Sekiranya cukup jelas bahwa Cascio dan Boudreau menjelaskan bahwa kemangkiran adalah bentuk kegagalan karyawan mematuhi jadwal kerjanya dan kegagalan untuk melaporkan apa yang seharusnya menjadi kewajibannya terhadap organisasi.

Menurut Fitz (2009:48)," absenteeism is an expense to the company, in that the work ascribed to a given job is not getting done by the person paid to do it when he or she is absent." Fitz menjelaskan bahwa kemangkiran adalah beban bagi perusahaan. Kemangkiran ini dianggap berasal dari tugas yang dibebankan pada pegawai, namun tugas tersebut tidak dapat diselesaikan ketika orang tersebut tidak hadir. Dari pendapat Fitz, dapat dipahami bahwa tugas yang dibebankan kepada karyawan adalah tugas yang harus dilaksanakan oleh karyawan. Artinya, apabila karyawan tidak hadir pada tempat kerjanya atau mangkir, maka hal ini akan menjadi beban bagi organisasi. Demikian Fitz menjelaskan kemangkiran menjadi beban bagi organisasi. Selanjutnya menurut Griffin and Moorhead (2014:79),"some absenteeism has a legimate cause, such as illness, jury duty, or a death or illness in the family. At other times, the employee may report a feigned legitimate cause that's actually just an execuse to stay home. When an employee is absent, legitimately or not, her or his work does not get done at all or a substitute must be hired to do it. In either case, the quantity or quality of actual outputis likely to suffer". Berdasarkan penjelasan di atas, kemangkiran terkadang dapat memiliki alasan sah seperti sakit, tugas, atau alasan karena ada anggota keluarga yang sakit. Namun terkadang seorang karyawan berpura-pura menggunakan alasan yang sah padahal karena dia ingin tinggal di rumah. Dengan kata lain kemangkiran dapat memiliki penyebab yang sah sehingga ketidakhadirannya dapat diterima organisasi tetapi karyawan juga dapat memanfaatkan alasan yang sah ini hanya untuk menghindari masuk kerja.

Berdasarkan penjelasan di atas maka sintesis kemangkiran adalah penilaian pimpinan terhadap perilaku individu dalam bekerja yang tidak dapat menyelesaikan pekerjaan sesuai jadwal, dengan indikator: kegagalan untuk 
melaporkan pekerjaan atau tetap bekerja sesuai jadwal, kegagalan dari menyelesaikan tugas sesuai jadwal, dan ketidakhadiran.

\section{Stres}

Menurut Wagner dan Hollenbeck (2010:107), "stress is an unpleasant emotional state that results when someone is uncertain of his or her capacity to resolve a perceived challenge to an important value." Wagner dan Hollenbeck mengemukakan bahwa stres adalah keadaan emosional yang tidak menyenangkan sebagai akibat dari ketidakpastian yang dialami pegawai dalam kapasitasnya menghadapi tantangan untuk nilai yang dianggap penting. Hampir sama dengan pendapat-pendapat sebelumnya, bahwa stres adalah respon emosional terhadap stimulasi tertentu, tetapi Wagner dan Hollenbeck menggarisbawahi bahwa stres sebagai respon emosi yang kurang menyenangkan dalam menghadapi tantangan. Griffin dan Moorhead (2007:48), "responsibility is an obligation to do something with the expectation of achieving some act output". Tanggung jawab adalah kewajiban untuk melakukan sesuatu dengan harapan mencapai beberapa tindakan atau output

Hal senada di ungkapkan oleh Robbins dan Judge (2015:38), "stress is a dynamic condition in which an individual is confronted with an opportunity, demand or resource related to what the individual desires and for which the outcome is perceived to be both uncertain and important." Definisi stres dikatakan adalah suatu kondisi dinamis dimana seorang individu dihadapkan pada peluang, tuntutan dan sumber daya yang terkait dengan apa yang dihasratkan oleh individu yang hasilnya dipandang tidak pasti dan penting.

Terkait dengan stres Fred Luthans (2011:279) mengemukakan,"stress is defined as an adaptive response to an external situation that results in physical, psychological and behavioral deviations for organizational participants". Stres diartikan sebagai respons adaptif terhadap situasi eksternal yang menghasilkan penyimpangan fisik, psikologis dan perilaku pada anggota organisasi.

Berdasarkan uraian di atas maka disintesiskan bahwa stres adalah situasi ketegangan, tekanan emosional yang dialami pegawai yang dapat mempengaruhi kondisi fisik, emosi, pikiran dan perilaku pegawai, dengan indikator: gejala fisik, gejala psikologis, gejala kognitif, dan gejala perilaku individu.

\section{Kepuasan Kerja}

Menurut Kinicki dan Kreitner (2010:170), "job satisfaction is an affective or emosional response toward various facets of one job." Kepuasan kerja adalah respon afektif atau emosional terhadap berbagai aspek dari suatu pekerjaan. Respon tersebut muncul sebagai refleksi atas terpenuhinya atau tidaknya kebutuhan dan keinginan individu yang didapat dari pekerjaannya saat ini.

Senada dengan pendapat Kinicki dan Kreitner, George, dan Jones (2012:71) menyatakan bahwa,"job satisfaction is the collection of feelings and beliefs that people have about their current jobs." Kepuasan kerja adalah kumpulan perasaan dan keyakinan yang mereka miliki mengenai pekerjaannya saat ini. Dapat dipahami bahwa, respon 
yang muncul terhadap berbagai aspek pekerjaan tersebut dalam bentuk kumpulan perasaan dan keyakinan.

Sementara itu, Ivancevich (2009:102) mengemukakan bahwa,"job satisfaction is an attitude that individuals have about their jobs. It results from their perception of their jobs, based on factors of the work environment, such as the supervisor's style, policies, and procedures, work group affiliation, working condition, and fringe benefits." Kepuasan kerja merupakan sebuah sikap yang dimiliki pekerja mengenai pekerjaannya. Kepuasan kerja tergantung dari tingkat hasil keluaran secara instrinsik dan ekstrinsik dan bagaimana pekerja memandang hasil keluaran tersebut. Keluaran secara instrinsik berupa perasaan yang datang dari pekerja sendiri terhadap pekerjaannya seperti perasaan tanggungjawab, tantangan dan pengakuan. Biasanya perasaan itu hasil dari karakteristik pekerjaan seperti otonomi, keanekaragaman tugas, identitas, dan signifikansi. Sedangkan keluaran ekstrinsik bersumber dari lingkungan pekerjaan pekerja mulai dari upah gaji, kondisi pekerjaan, rekan kerja bahkan supervise

Mengenai hal ini, Schermerhorn (2010:72) menjelaskan bahwa,"job satisfaction, an attitude reflecting a person's positive and negative feelings toward a job, co-workers and the work environment." Kepuasan kerja merupakan suatu sikap yang mencerminkan perasaan positif dan negatif dari hasil penilaian pegawai terhadap pekerjaan, rekan kerja dan lingkungan kerja.

Berdasarkan uraian di atas maka dapat disintesiskan bahwa kepuasan kerja adalah respon perasaan positif mengenai pekerjaan yang merupakan hasil evaluasi terhadap karakteristik aspek-aspek yang berbeda dari pekerjaan, dengan indikator: perasaan terhadap pengaturan pekerjaan, perasaan terhadap situasi pekerjaan, perasaan terhadap pengakuan atas hasil kerja, dan perasaan terhadap penghargaan atas hasil kerja.

\section{METODE}

Penelitian ini dilaksanakan pada pegawai Dinas Pendidikan, Pemuda dan Olahraga Kota Bukittinggi Provinsi Sumatera Barat selama 3 (tiga) bulan. Metode yang digunakan dalam penelitian ini adalah survey dengan menggunakan teknik kausal. Populasi adalah pegawai Dinas Pendidikan, Pemuda dan Olahraga Kota Bukittinggi Provinsi Sumatera Barat yang berjumlah 103 pegawai dengan jumlah sampel sebanyak 82 pegawai. Data yang dikumpulkan dalam penelitian dijaring melalui kuesioner yang berupa skala penilaian (rating scale) dengan sebaran skor antara 1 sampai dengan 5 .

Setelah dilakukan analisis deskriptif dilanjutkan dengan uji persyaratan analisis berupa uji normalitas, uji linearitas data dan keberartian regresi, dilakukan uji hipotesis dengan menggunakan teknik analisis jalur (path analysis).

\section{HASIL DAN PEMBAHASAN}

\section{Pengaruh Stres terhadap Kemangkiran}

Hasil penelitan ini menunjukkan bahwa terdapat pengaruh langsung positif stres terhadap kemangkiran dengan nilai koefisien korelasi sebesar 0,457 dan nilai 
koefisien jalur sebesar 0,344. Ini memberikan makna stres berpengaruh langsung positif terhadap kemangkiran.

Jika temuan ini diinterpretasikan, maka meningkatnya stres yang dialami oleh pegawai Dinas Pendidikan, Pemuda dan Olahraga Kota Bukittinggi Provinsi Sumatera Barat mengakibatkan peningkatan kemangkiran pegawai tersebut. Kegagalan pegawai Dinas Pendidikan, Pemuda dan Olahraga Kota Bukittinggi Provinsi Sumatera Barat untuk melaporkan pekerjaan atau tetap bekerja sesuai jadwal, kegagalan dari menyelesaikan tugas sesuai jadwal dan ketidakhadiran pada jam kerja akan mengalami peningkatan ketika stres yang dialami pegawai Dinas Pendidikan, Pemuda dan Olahraga Kota Bukittinggi Provinsi Sumatera Barat yang terlihat melalui gejala fisik (seperti sakit kepala, mual, detak jantung meningkat saat melaksanakan tugas yang dibebankan), gejala psikologis (seperti gelisah, frustasi, dan mudah marah), gejala kognitif (seperti rendahnya konsentrasi dan kurang percaya diri) dan gejala perilaku (seperti ceroboh dan ragu-ragu dalam melaksanakan tugas) juga mengalami peningkatan.

Hasil penelitian ini senada dengan pendapat beberapa ahli di antaranya, menurut Griffin dan Moorhead (2014:193)," withdrawal behaviors also can result from stress. For the organization, the two most significant forms of withdrawal behavior are absenteeism and quitting." Menurut mereka, ada banyak perilaku penarikan diri yang muncul dari stres. Bagi sebuah organisasi, ada dua bentuk signifikan dari perilaku penarikan diri, yaitu mangkir dan keluar dari pekerjaan. Sehingga, ketika pegawai mengalami stres dan ingin menarik diri, maka pegawai tersebut akan mangkir dari pekerjaannya atau bahkan keluar dari pekerjaan tersebut.

Schermerhorn dkk (2010:38) berpendapat,"too much stress can overload and break down a person's physical and mental systems resulting in absenteeism, turnover, errors, accidents, dissatisfactions, reduced performance, unethical behavior, and even illness." Terlalu stres dapat menyebabkan beban menjadi lebih berat dan menurunkan kondisi fisik dan sistem mental pegawai yang mengakibatkan ketidakhadiran, pengunduran diri, kesalahan, kecelakaan, ketidakpuasan, turunnya prestasi, perilaku tidak pantas dan bahkan penyakit.

\section{Pengaruh Langsung Kepuasan Kerja terhadap Kemangkiran}

Hasil penelitan ini menunjukkan bahwa terdapat pengaruh langsung negatif kepuasan kerja terhadap kemangkiran dengan nilai koefisien korelasi sebesar -0,454 dan nilai koefisien jalur sebesar -0,339. Ini memberikan makna kepuasan kerja berpengaruh langsung negatif terhadap kemangkiran.

Jika temuan ini diinterpretasikan, maka meningkatnya kepuasan kerja yang dialami oleh pegawai Dinas Pendidikan, Pemuda dan Olahraga Kota Bukittinggi Provinsi Sumatera Barat mengakibatkan penurunan kemangkiran pegawai tersebut. Kegagalan pegawai Dinas Pendidikan, Pemuda dan Olahraga Kota Bukittinggi Provinsi Sumatera Barat untuk melaporkan pekerjaan atau tetap bekerja sesuai jadwal, kegagalan dari menyelesaikan tugas sesuai jadwal dan ketidakhadiran pada jam kerja akan mengalami penurunan ketika kepuasan kerja yang diperoleh 
pegawai yang terlihat dari perasaan pegawai terhadap pengaturan pekerjaan (seperti kesempatan yang diterima pegawai dalam mengembangkan potensi di tempat kerja), perasaan terhadap situasi pekerjaan (seperti hubungan kerjasama yang terbentuk antara pegawai dengan rekan kerja), perasaan terhadap pengakuan hasil pekerjaan (seperti pengakuan pimpinan atas hasil kerja yang telah dilakukan oleh pegawai) dan perasaan terhadap penghargaan atas hasil kerja (seperti kenaikan jenjang karir atas pretasi yang dicapai oleh pegawai) mengalami peningkatan.

Hasil penelitian ini senada dengan pendapat beberapa ahli di antaranya adalah McShane (2013:109) yang menyatakan bahwa,"job satisfaction affects many of the individual behaviors... (Task performance, organizational citizenship, quitting, absenteeism, etc.)." Kepuasan kerja mempengaruhi banyak perilaku individu (kinerja, OCB, keluar dari pekerjaan, kemangkiran, dan lain-lain).

Sejalan dengan McShane, Moorhead dan Griffin (2012:190) menyatakan bahwa, "a satisfied employee tends to be absent less often, to make positive contributions and to stay with the organization. In contrast, a dissatisfied employee may be absent more often, may experience stress that disrupts coworkers, and may be continually looking for another job." Menurut Moorhead dan Griffin, pegawai yang puas dengan pekerjaannya cenderung jarang mangkir dari pekerjaannya, memberikan kontribusi yang positif dan loyal dengan organisasi/ lembaga tempat bekerja. Kondisi ini berbeda dengan pegawai yang tidak puas dengan pekerjaannya. Pegawai yang tidak puas dengan pekerjaannya akan lebih sering mangkir, mengalami stres yang mengganggu pekerjaannya dan mungkin berlanjut mencari pekerjaan lain. Hal ini menunjukkan bahwa kepuasan kerja dapat mempengaruhi kemangkiran pegawai.

Hellriegel dan Slocum (2011:88) juga menjelaskan mengenai hal yang mempengaruhi kemangkiran,"low job satisfaction can result in costly turnover, absenteeism, tardiness and even poor mental health. Rendahnya kepuasan kerja dapat mengakibatkan kepindahan kerja, kemangkiran, keterlambatan dan bahkan gangguan jiwa.

Sejalan dengan Hellriegel dan Slocum, Schermerhorn (2010:79) mengungkapkan,"job satisfaction influences with drawl behavior such as absenteeism, turnover, day dreaming and cyber loafing." Kepuasan kerja mempengaruhi sikap menyimpang seperti kemangkiran, kepindahan kerja, melamun dan penyimpangan dunia maya.

Lebih lanjut Newstrom (2013:251) menyatakan bahwa,"job dissatisfaction may lead to increased absenteeism, turnover, and other undesirable behavior, so employers want to develop satisfaction among their employees." Menurut Newstrom, ketidakpuasan kerja yang dialami oleh para pegawai akan meningkatkan terjadinya kemangkiran, kepindahan kerja, dan perilaku yang lainnya yang diharapkan tidak terjadi dalam suatu lembaga/ organisasi. Oleh karena, para pimpinan lembaga/ organisasi perlu mengembangkan kepuasan kerja dari para pegawai untuk mencegah terjadinya perilaku yang tidak diharapkan tersebut. 


\section{Pengaruh Langsung Stres terhadap Kepuasan Kerja}

Hasil penelitan ini menunjukkan bahwa terdapat pengaruh langsung negatif stres terhadap kepuasan kerja dengan nilai koefisien korelasi sebesar -0,334 dan nilai koefisien jalur sebesar -0,334. Ini memberikan makna stres berpengaruh langsung negatif terhadap kepuasan kerja.

Jika temuan ini diinterpretasikan, maka meningkatnya stres yang dialami oleh pegawai Dinas Pendidikan, Pemuda dan Olahraga Kota Bukittinggi Provinsi Sumatera Barat mengakibatkan penurunan kepuasan kerja pegawai tersebut. Kepuasan kerja yang diperoleh pegawai Dinas Pendidikan, Pemuda dan Olahraga Kota Bukittinggi Provinsi Sumatera Barat yang terlihat dari perasaan pegawai dalam mengembangkan potensi di tempat kerja), perasaan pegawai terhadap situasi pekerjaan (seperti hubungan kerjasama yang terbentuk antara pegawai dengan rekan kerja), perasaan pegawai terhadap pengakuan hasil pekerjaan (seperti pengakuan pimpinan atas hasil kerja yang telah dilakukan oleh pegawai) dan perasaan pegawai terhadap penghargaan atas hasil kerja (seperti kenaikan jenjang karir atas pretasi yang dicapai oleh pegawai) akan mengalami penurunan ketika stres yang dialami pegawai yang terlihat melalui gejala fisik (seperti sakit kepala, mual, detak jantung meningkat saat melaksanakan tugas yang dibebankan), gejala psikologis (seperti gelisah, frustasi, dan mudah marah), gejala kognitif (seperti rendahnya konsentrasi dan kurang percaya diri) dan gejala perilaku (seperti ceroboh dan ragu-ragu dalam melaksanakan tugas) mengalami peningkatan.

Hasil penelitian ini senada dengan pendapat beberapa ahli di antaranya adalah George dan Jones (2012:248) yang menyatakan bahwa,"highly stressed employees tend to have a more negative outlook on various aspects of their jobs and organizations and are more likely to have low levels of job satisfaction and organizational commitment." Pegawai dengan tingkat stres yang tinggi cenderung memiliki pandangan yang negatif pada berbagai aspek pekerjaan mereka dan organisasi dan memiliki kepuasan kerja dan komitmen organisasi yang lebih rendah.

Sejalan dengan pendapat Ivancevich, Mullins (2005:706) menyatakan bahwa,"stress at work is the biggest problem in European companies. There appears little doubt that one of the major adverse influences on job satisfaction, work performance and productivity, and absenteeism and turnover is the incidence of stress at work." Stres kerja merupakan masalah yang paling besar di perusahaan Eropa. Ada dugaan bahwa hal utama yang mempengaruhi kepuasan kerja, kinerja, dan produktifitas, dan kemangkiran serta turnover adalah stres kerja.

Dengan demikian, beberapa temuan di atas semakin mempertegaskan bahwa stres merupakan faktor yang berpengaruh langsung negatif terhadap kepuasan kerja.

\section{PENUTUP}

Kesimpulan: (1) Stres berpengaruh langsung positif terhadap kemangkiran. Artinya, peningkatan stres mengakibatkan peningkatan kemangkiran pegawai Dinas Pendidikan, Pemuda dan Olahraga Kota Bukittinggi Provinsi Sumatera Barat; (2) 
Kepuasan kerja berpengaruh langsung negatif terhadap kemangkiran. Artinya, peningkatan kepuasan kerja mengakibatkan penurunan kemangkiran pegawai Dinas Pendidikan, Pemuda dan Olahraga Kota Bukittinggi Provinsi Sumatera Barat; (3) Stres berpengaruh langsung negatif terhadap kepuasan kerja. Artinya, peningkatan stres mengakibatkan penurunan kepuasan kerja pegawai Dinas Pendidikan, Pemuda dan Olahraga Kota Bukittinggi Provinsi Sumatera Barat.

Saran: Pertama, Kepala Dinas Pendidikan, Pemuda dan Olahraga Kota Bukittinggi Provinsi Sumatera Barat selaku pengambil kebijakan tertinggi di satuan pendidikan tingkat kabupaten/kota perlu memperhatikan berbagai variabel berkenaan dengan upaya penurunan kemangkiran pegawai Dinas Pendidikan, Pemuda dan Olahraga Kota Bukittinggi Provinsi Sumatera Barat. Stres dan kepuasan kerja merupakan variabel yang sangat disarankan untuk diperhatikan dan dipahami serta diterapkan agar kemangkiran pegawai dapat diturunkan secara signifikan yang tentunya hal tersebut menjadi harapan bersama.

Kedua, Diharapkan bagi para peneliti selanjutnya agar menindaklanjuti penelitian ini melalui penelitian-penelitian serupa dengan mengembangkan variabel-variabel bebas dan cakupan wilayah penelitian. Hal ini disebabkan masih banyak faktor yang mempengaruhi stres, kepuasan kerja dan kemangkiran.

\section{DAFTAR RUJUKAN}

A. Wagner III, John dan John R. Hollenbeck. Organizational Behavior: Securing Competitive Advantage. New York: Taylor \& Francis, 2010.

A. Colquitt, Jason, Jeffry A. LePine dan Michael J. Wesson. Organizational Behavior: Improving Performance and Commitment in the Workplace, $4^{\text {th }}$. ed. United States of America: McGraw-Hill, 2015.

Amstrong, Michael. A Handbook of Human Resource Management Practice, $10^{\text {th }}$. ed. London and Philadelphia: Kopan Page, 2006.

------. Amstrong's Handbook of Human Resource Management Practice, 11 $1^{\text {th }}$ ed. Philadelphia: Kogan Page, 2009.

Anderson, Neil, et.al. Handbook of Industrial: Work and Organizational Psychology. London: SAGE Publications, 2001.

Cascio, Wayne dan John Boudreau. Investing in People: Financial Impact of Human Resource Initiatives, 2nd. ed. New Jersey: Pearson Education, 2011. 
Herriegel, Don dan John W. Slocum, Jr. Organizational Behavior, 13 $3^{\text {th }}$ ed. USA: SouthWestern Cengage Learning, 2011.

Ivancevich, Gibson, Donelly, dan Robert Konopaske. Organizations Behavior and Management, 14th. ed. New York: McGraw-Hill, 2009.

J.Mullins, Laurie. Management and Organisational Behaviour, $7^{\text {th. }}$ ed. England: Prentice Hall, 2005.

JacFitz. The ROI of Human Capital: Measuring the Economic Value of Emloyee Perfomance, $2^{\text {nd. }}$ ed. New York: AMACOM, 2009.

Jeff Harris, O dan Sandra J. Hartman. Organizational Behavior. New York: Haworth Press, Inc, 2002.

Kondalkar, V.G. Organizational Behavior. New Delhi: New Age International, 2007.

Kreitner, Robert dan Angelo Kinicki. Organizational Behavior, 9th. ed. New York: McGraw Hill- Irwin, 2010.

L. McShane, Steven dan Mary Ann Von Glinov. Organizational Behavior: Emerging Knowledge and Practice for the Real World, 5th. ed. New York: McGraw-Hill Companies, 2010.

------. Organizational Behavior: Emerging Realities for the Workplace Revolution, $4^{\text {th }}$. ed. New York: McGraw-Hill/Irwin, 2008.

L. Gibson, James, John M. Ivancevic dan James H. Donelly Jr. Organizations: Behavior, Structure, Processes, 14th. ed. New York: McGraw-Hill, 2012.

Locke, Edwin. Handbook of Principles Organization Behavior Indispensible Knowledge for Evidence-Based Management, 2nd. ed. West Sussex: John Willey \& Son, 2009.

Luthans, Fred. Organizational Behavior: An Evidence-Based Approach, 12 th ed. New York: McGraw-Hill/Irwin, 2011.

M. George, Jennifer dan Gareth R. Jones. Understanding and Managing Organizational Behavior, 6 6h $^{\text {th }}$ ed. New Jersey: Pearson Education, 2012.

M. Jex, Steve dan Thomas W. Britt. Organizational Psychology: A Scientist-Practicioner Approach, 2nd. ed. New York: John Wesley \& Sons, 2002. 
McShane. Organizational Behavior, $6^{\text {th }}$. ed. Singapore: McGraw-Hill Education (Asia), 2013.

P. Robbins, Stephen dan Timothy A. Judge. Organizational Behavior, $16^{\text {th }}$. ed. England: Pearson Education Limited, 2015.

Perilaku Organisasi, (Terjemahan), 12th. ed. Jakarta: Salemba, 2008.

----------. Organizational Behavior, 15 ${ }^{\text {th }}$ ed. USA: Pearson Prentice Hall, 2013.

Pilbeam, Stephen dan Marjorie Corbridge. People Resourcing: Contemporary HRM in Practice, $3^{\text {rd }}$. ed. Harlow: Pearson Education Limited, 2006.

R. Schermerhorn, Jr., John, James G. Hunt, Richard N. Osborn dan Mary Uhl-Bien. Organizational Behavior, 11 th. ed. Hoboken: John Wiley \& Sons, 2010.

Stranks, Jeremy. Stress at Work Management and Prevention. Burlington: Elsevier Butterworth-Heinemann, 2005.

W. Griffin, Ricky dan Gregory Moorhead. Managing Organizational Behavior, 10 ${ }^{\text {th }}$. ed. South Western: Cengage Learning, 2012.

-. Organizational Behavior: Managing People and Organizations, 11th. ed. Mason: Cengage Learning, 2014.

W. Newstrom, John. Organizational Behavior: Human Behavior at Work, $13^{\text {th }}$. ed. Singapore: McGraw-Hill Education (Asia), 2013. 